\title{
Regional Innovation Capacity in Development Regions and Cities: A Sustainable Approach
}

\author{
Peyman Pournasr Khakbaz \\ Islamic Azad University, Science and Research Branch, Tehran, Iran \\ p.pournasr@yahoo.com
}

\begin{abstract}
This paper aims to identify innovation capacity factors affecting the development of regional by using the main index of legal and regulatory framework, research and development, communications and information technology, environment and institutional and human capital, education and social coverage. The research method is Qualitative and by focal group. Therefore, by choosing 6 from academic experts, the group was formed. To clarify the principles and basic format, explanations about of the meeting and a detailed description of the research model presented. Then to get more accurate and clearer data, and 5 core indicators parted to theirs sub indicators and the group members discussed them. The results showed that all five the main index of the "institutional environment", "R\&D"1, "Using information and communication technology", "Legal and regulatory framework" and "human capital, education and social coverage" are impact on the development of region. The "country politic assessment " and "efficient and proper administration" which are two sub indicators of institutional environment and tow sub indicators of human capital, education and social coverage which are education and social coverage have impact on regional development. Also doing business and infrastructure of R\&D which are sub indicators of legal and regulatory framework and R\&D have impact on regional development. In the sub indicators of communications and information technology, "internet, computer and TV" and "government using of ICT "and quality of infrastructures have impact on regional development.
\end{abstract}

Key words: Regional development, innovation capacity, focal group

\section{Introduction}

Today, innovation has been clearly identified as the key to competitive advantage. Cooke and Memedovic (2003) notes that an increasing interest is being raised among local decision-makers on the fact that economical growth and competitive advantage are highly dependent on the capacity of local companies for innovation. Providing enough support to local firms in the way to get more competitive through innovation is one of the important discussions in regional policies (Cohen and Levinthal, 2008). Recently, the concept of innovative capacity, which determines the potential and active capabilities of a system to change knowledge to innovation, has emerged in the political and academic areas (Freeman, 1995). Innovative capacity is studied by scientists and scholars to determine the factors and determinants affecting innovative dynamism and local and regional capacities (Cohen and Levinthal, 2008; Furman et al (2000). The present paper reviews Claros 's model (2009) as well as the comments of experts and scientists in the area of regional development to determine the innovative capacity factors affecting regional development.

\section{Literature Review}

Innovative capacity is the potential power of an agent/country in doing innovative activities including the introduction and supply of new products and services, procedures and processes and new ideas related to the organization (Archibugi and Michie, 1995). In addition, Balconi et al (2004) in his research find innovative capacity as an intermediary factor, which changes the provocative factors and innovative motivations into outputs like innovation in production and process (Archibugi and Michie, 1995). The positive and negative factors affecting regional innovative capacity is examined in different countries: Asheim (1996) in his article believes that technical infrastructures support regional innovative capacities. Albino et al (2007) emphasize the importance of holding relations to facilitate the accessibility to complimentary knowledge resources to improve skills, capabilities and norms. Becattini (1990) investigates the effects of social capital on regional innovative activities. Camagni (1991) believes infrastructural innovation and specific innovative environment is considered as one of the most

\footnotetext{
${ }^{1}$-research and development
} 
important dynamics for national or regional innovative capacity. Cooke and Memedovic (2003) believes regional beneficial organizations, network activities and local context are the three factors affecting innovative capacity. Regional innovative capacities require a deep understanding of the nature of capabilities and capacities needed for innovation. In addition, capabilities and definitions of strategies need to be determined to enable exploiting the capacities. According to Dakhli and De Clercq (2004) knowledge-based capital, including human capital, structural capital, relational capital and cultural capital, each has reinforcing effect on innovative capacity and regional development. Doloreux (2002) argues that innovative processes and capabilities affect the regional innovative capability.

The emphasis on improving and creating innovation zone through developing environmental development, with social systems such as regional innovation systems, innovative environment, industrial zones, and new industrial spaces. It is widely recognized nowadays that innovation is a central driving force of competitiveness and value creation. Edqvist (2004) highlight that "there is a growing awareness among regional authorities that the economic growth and competitiveness of their regions depend largely on the capacity of indigenous firms to innovate. Offering the appropriate support to indigenous firms to become more competitive through innovation is a rising star on the regional policy agenda". Archibugi and Michie (1995) state that "the production and use of knowledge is at the core of value-added activities, and innovation is at the core of firms' and nations' strategies for growth". Tura and Harmaakorpi (2005), reviewing a number of theoretical frameworks and notions about regional innovation, have highlighted the importance of building and enhancing regional innovativeness by developing an environment characterized by networked systems, such as regional innovation systems (Cooke et al., 2004; Doloreux, 2002), innovative milieu (Camagni, 1991), industrial districts (Marshall, 1916; Piore and Sabel, 1984; Becattini, 1990), new industrial spaces (Storper, 1997; Storper, 1995), and learning regions (Florida, 1995; Asheim, 1996).

From a policy perspective, The Council on Competitiveness Organization (2005) has underlined the relevance of the regional context to develop innovation capabilities. In particular, it has been argued that innovation requires long-term cooperation between investors, entrepreneurs, researchers, firms, public authorities and consumers. Such relations flourish more easily at regional level, enjoying benefits from short distances that facilitate both formal and informal contacts. Regional-based cooperation networks are ideal knowledge sources and entry points to exchange information and to set up new ideas (Council on Competitiveness, 2005). Furman et al (2000) underline that innovation capacity is related to, but distinct from, scientific and technical advances per se, and it is distinct from current national industrial competitive advantages or productivity. It mainly reflects variation in both economic geography and innovation policy. A wide literature has analyzed the different elements positively or negatively influencing regional innovation capacity. The analysis developed by Tura and Harmaakorpi (2005) allows the identification of two fundamental aspects affecting the development of a regional innovation capacity:

- the innovation processes; and

- The innovative capabilities.

Strictly related to the innovation processes, the following dimensions influencing regional innovation capacity can be outlined:

- The gradual, social and cumulative character of innovation processes, which are based on continuous learning processes carried out by regional stakeholders engaged directly or indirectly in regional innovation networks (Edqvist, 2004).

- The integration of different and numerous technological and organizational knowledge inputs, derived from other sectors and regions, which allows expertise to be renewed and new problems to be solved (Albino et al., 2007; Katz and Kahn, 1996).

- The interactive character of the learning processes, which involves networking among firms as well as dynamism in local social networks. This requires the development of linkages, networks and cooperation between different stakeholders, outside the channels of existing institutional structures (Lundvall, 1992).

- The characteristics of the boundaries of the innovation dynamics at regional level (Cooke et al., 2004; Malerba, 2002; Malerba and Orsenigo, 1995).

The present research adopts the conceptual model of Claros (2009). The model has 5 main indices: 1. Legal and regulatory framework. 2. R\&D. 3. Using communication and information technologies. 4. Institutional environment and 5. Human capital, education and social coverage. Each index has some subsections. The legal framework includes doing business factor and the research and development 
includes 1. Issues related to R\&D, 2. Trademarks and patent, communication technology index including 1. Immobile communications, 2. Mobile communications, 3. Internet, computer and television, 4. Using communication and information technologies by the government. 5 . The quality of infrastructures, the quality of institutional environment including 1. A qualified government, 2. Evaluating the national policies, and social capital index, education and social coverage including 1 . Training 2. Social coverage and fair policies.

\section{Methodology}

Focal group method was used for identifying the innovative capacity factors affecting regional development. Focal group is a qualitative method, which is used for negotiation designed according to an accurate program to investigate the thoughts of the interviewees in an environment without pressure and threat and leads to a precise testing of the related issues. The statistical population is 6 entrepreneurial academic and regional decision-maker experts. During the meeting, principal instructions were provided to the respondents about the framework of the meeting. In the next step, the subject was introduced through five key questions derived from the research model. It is worthy to note that experts in this area are few. Then, for getting more precise data, the general questions were broken to more specific one and were discussed among the respondents.

\section{Conclusion}

The present paper attempts to identify innovative capacity affecting economical development through reviewing the related literature on "innovative capacity" and "economical development". In this regard, using the conceptual models of innovative capacity by Yasmina Mata and Lopez Carlos and using "focal group" method, we tried to identify the above mentioned factors the results of which is presented below: After a group discussion on the research questions and registering the information with full detail, the results of the findings was summed up as: all of the main indices of "institutional environment", "R\&D", " using communication and information technologies by the government", " Legal and regulatory framework", "Human capital, education and social coverage" affect regional development. Two subindices of "institutional environment" and "evaluating the national policy" and "qualified government" and two sub-indices of "human capital, education and social coverage", that is "education" and "social coverage and fair policies" affect the regional development. It was also founded that the sub-indices of "legal and regulatory framework", that is "doing business" as well as "R\&D" which is "the infrastructure of R\&D" affects regional development. The sub-indices affecting "using communication and information technologies" include the sub-indices of "internet, computer and television", " using communication and information technologies by the government " and "the quality of infrastructures".

Suggestions: The findings of the research showed that all of the main innovation capacity factors affect regional development. In this regard, the following suggestions are given:

- If a nation is on the way to reach regional development and political stability, in institutional environment, the two sub-indices must be considered seriously.

- Regarding human capital, education and social coverage, we need to higher the literacy, education, and act fairly in political and economical issues.

- To achieve regional development, we need to facilitate business trends and businesses to reinforce innovative capacity and help it through expanding the investment and increasing research and development share.

- In the fifth index, which is using communication and information technologies, we need to expand communication and information structures qualitatively and quantitatively. The government, also needs to use more of information and communication systems in its tasks. 


\section{References}

Albino, V., Carbonara, N. \& Messeni, P. A. (2007). Technology districts: proximity and knowledge access. Journal of Knowledge Management, 11, 98-114.

Asheim, B. T. (1996). Industrial districts as 'learning regions: a condition for prosperity? European Planning Studies, 4, 379-400.

Archibugi, D. \& Michie, J. (1995). Technology and innovation: an introduction. Cambridge Journal of Economics, 19, 1-4.

Balconi, M., Breschi, S. \& Lissoni, F. (2004). Networks of inventors and the location of academic research: an exploration of Italian patent data. Research Policy, 33(1), 127-45.

Becattini, G. (1990). The Marshallian industrial district as a socio-economic notion, in Pyke, F., Becattini, G. and Sengenberger, E. (Eds), Industrial Districts and Inter firm Cooperation in Italy, International Institute of Labour Studies, Geneva, 37-51.

Camagni, R. (1991). Local milieu, uncertainty and innovation networks: towards a new dynamic theory of economic space, in Camagni, R. (Ed.), Innovation Networks: Spatial Perspectives, Belhaven, London, 121-44.

Claros, A. 1. (2009). The Innovation Capacity Index: Factors, Policies, and Institutions Driving Country Innovation.

Cohen, W. M. \& Levinthal, D. (2008). Innovation and Learning: The Two Forces of R\&D. Economic Journal, 99, 569-596.

Cooke, P. \& Memedovic, O. (2003). Strategies for Regional Innovation Systems: Learning Transfer and Application Policy Papers, UNIDO, Vienna.

Cooke, P., Gomez, U. M. \& Extebarria, G. (2004). Regional innovation systems: institutional and organizational dimensions. Research Policy, 26, 475-91.

Dakhli, M. \& De-Clercq, D. (2004). Human capital, social capital, and innovation: a multi-country study. Entrepreneurship \& Regional Development, 16, 107-28.

Doloreux, D. (2002). What should we know about regional systems of innovation. Technology in Society, 24, 243-63.

Florida, R. (1995). Towards the learning region. Futures, 27, 527-36.

Freeman, C. (1995). The National System of Innovation in historical perspective. Cambridge Journal of Economi, 19, 5-24.

Edqvist, C. (2004). Systems of innovation - a critical review of the state of the art, in Fagerberg, J., Mowery, D. and Nelson, R. (Eds), Handbook of Innovation, Oxford University Press, Oxford.

Furman, L. J., Porter, E. M. \& Stern, S. (2000). The Determinants of National Innovative Capacity. JEL NO, 03, 033-057.

Katz, D. \& Kahn, R. (1996). The Social Psychology of Organizations, Wiley, New York, NY.

Lundvall, B. A. (1992). National Systems of Innovation: Towards a Theory of Innovation and Interactive Learning, Pinter, London.

Marshall, A. (1916). The Principles of Economics, Macmillan, London.

Malerba, F. (2002). Sectoral systems of innovation and production. Research Policy, 31(2), 247-64.

Malerba, F. \& Orsenigo, L. (1995). Schumpeterian patterns of innovation. Cambridge Journal of Economics, 19(1), 19-47.

Piore, M. \& Sabel, C. (1984). The Second Industrial Divide, Basic Books, New York, NY.

Storper, M. (1995). Competitiveness policy options: the technology-regions connection. Growth and Change, 285-308.

Storper, M. (1997). The Regional World: Territorial Development in a Global Economy, Guilford Press, New York, NY.

The Council on Competitiveness Organization. (2005). Measuring Regional Innovation, A Guidebook for Conducting Regional Innovation Assessments.

Tura, T. \& Harmaakorpi, V. (2005). Social capital in building regional innovative capability. Regional Studies, 39(8), 1111-25. 